\title{
Quality indicators in nutrition therapy within the intensive care setting of a Brazilian teaching hospital
}

\author{
Indicadores de qualidade em terapia nutricional no contexto de cuidados \\ intensivos em um hospital de ensino brasileiro \\ Indicadores de calidad en terapia nutricional em el contexto de cuidados \\ intensivos em un hospital universitário brasileño
}

\author{
Teresa Cristina Abranches Rosa ${ }^{1}$ \\ Mariana Raslan ${ }^{1}$ \\ Albert Schiaveto de Souza ${ }^{1}$ \\ Karine de Cássia Freitas Gielow ${ }^{1}$
}

Recebido em 19/12/2017; revisado e aprovado em 09/11/2018 aceito em 18/11/2018

DOI: http://dx.doi.org/10.20435/inter.v20i3.1759

\begin{abstract}
The topic addressed by this study was quality indicators in nutritional therapy. The aim was to evaluate the quality of nutritional therapy in an intensive care unit for adults in a Brazilian university hospital. Ten quality indicators selected from a list prepared by the Clinical Nutrition Task Force of the International Life Sciences Institute (ILSI-Brazil) were applied. It was observed that the use of quality indicators of nutritional therapy allowed the identification of compliance and nonconformity processes, which still need additional adjustments.
\end{abstract}

Keywords: nutrition therapy; quality indicators, health care; enteral nutrition; parenteral nutrition; quality management.

Resumo: O tema abordado pelo estudo foi indicadores de qualidade em terapia nutricional. O objetivo foi avaliar a qualidade da terapia nutricional em uma unidade de terapia intensiva para adultos em um hospital universitário brasileiro. Realizou-se a aplicação de dez indicadores de qualidade selecionados de uma lista elaborada pela Força Tarefa de Nutrição Clínica do International Life Sciences Institute (ILSI-Brasil). Observouse que o uso de indicadores de qualidade de terapia nutricional permitiu a identificação de processos em conformidade e em não-conformidade, que ainda precisam de ajustes adicionais.

Palavras-chave: terapia nutricional; indicadores de qualidade em assistência à saúde; nutrição enteral; nutrição parenteral; gestão da qualidade.

Resumen: El tema abordado por el studio fue indicadores de calidad en la terapia nutricional. El objetivo fue evaluar la calidad de la terapia nutricional en una unidad de cuidados intensivos para adultos en un hospital universitario brasileño. Se aplicaron diez indicadores de calidad seleccionados de una lista preparada por el Grupo de trabajo de nutrición clínica del Instituto Internacional de Ciencias de la Vida (ILSI-Brasil). Se observó que el uso de indicadores de calidad de la terapia nutricion al permitió la identificación de los procesos de cumplimiento y no conformidad, que aún requieren ajustes adicionales.

Palabras clave: terapia nutricional; indicadores de calidad de la atención de salud; nutrición enteral; nutrición parenteral; gestión de la calidad.

\section{INTRODUCTION}

Malnutrition is still a recurring finding that negatively impacts the patient's prognosis, reduces bed turnover, and increased hospital costs. Due to the fact that nutritional status interferes directly with clinical evolution, nutritional therapy (TN) is a therapeutic alternative for recovery or maintenance of nutritional status when the total or partial impossibility of oral feeding occurs. However, despite the existence of legislation, consensus and guidelines for implementation of nutritional therapy, studies still point to problems such as delayed onset of

\footnotetext{
${ }^{1}$ Universidade Federal de Mato Grosso do Sul (UFMS), Campo Grande, Mato Grosso do Sul, Brasil.
} 
therapy, inadequate prescription and administration, metabolic and gastrointestinal complications, conduct discrepancies, among others (CUNHA; SALLUH; FRANCA, 2010). Thus, the idea of incorporating the overall quality management in patient care, allowing to identify and to reduce the non-conformity between the predicted and the daily reality of nutritional therapy. Thus, all patients on nutritional therapy should be monitored routinely, and this evaluation should ensure assertive behaviors and favorable outcomes, such as low-cost clinical recovery (WAITZBERG, 2008).

The purpose of intensive care units (ICUs) is to deliver healthcare to critically ill patients, and nutrition therapy is part of the intensive care arsenal-hence the interest in improving its effectiveness (VALENTIN; FERDINDANDE; ESICM..., 2011). However, inadequacies in nutritional support are a common occurrence in this setting (RIBAS; GARCIA; ABIB, 2014; SHIROMA et al., 2015; LEE et al., 2017).

Quality control in intensive care, a topic of increasing urgency and discussion, is equally pertinent to nutrition therapy. Quality indicators can allow improvements by measuring the effectiveness of a given process (VALENTIN; FERDINDANDE; ESICM..., 2011; VEROTTI et al., 2012; BRAUN et al., 2013). Despite the absence of set rules for applying indicators, the Clinical Nutrition Taskforce of the Brazilian chapter of the International Life Science Institute (ILSI-Brasil) has proposed a list of 36 indicators applicable to nutrition therapy (WAITZBERG, 2008).

Drawing on a consensus of healthcare professionals and the scientific community, Verotti et al. (2012) selected ten top indicators from the ILSI-Brasil list regarded as potentially most relevant and applicable. Other investigators have discussed and applied quality indicators, pointing out the importance of their use for continuous evaluation of nutrition therapy quality (VEROTTI et al., 2012; BRAUN et al., 2013; CENICCOLA; ARAÚJO; AKUTSU, 2014).

In this context, the aim of the present study was to evaluate the quality and effectiveness of current nutritional therapy practices in the adult ICU of a teaching hospital applying nutritional therapy quality indicators (NTQIs).

\section{MATERIALS AND METHODS}

For this observational, cross-sectional, retrospective investigation, secondary data were collected from the records of patients treated at the adult ICU of a teaching hospital in Campo Grande county, Mato Grosso do Sul state, Midwest Brazil, between July 1, 2012, and July 31, 2013.

Criteria for inclusion were as follows: being 18 years of age or older and having received enteral nutrition therapy (ENT), parenteral nutrition therapy (PNP), or both. Data collection was carried out by a trained researcher and entered in a semi-structured form. The variables investigated were age, sex, diagnosis, clinical outcome, and length of hospital stay, supplemented with information required for the evaluation of quality indicators. Statistical analysis was performed using SPSS software, version 22.0, adopting a significance level of 5\%. Target quality rates and the formula for calculating indicators were those proposed by Waitzberg (2008). NTQIs were expressed as percent or per mil target rates, as recommended by ILSI-Brasil.

The study was approved by the Research Ethics Committee of the Federal University of Mato Grosso do Sul (permit 438 328, issued 28, Oct. 2013). 


\section{RESULTS AND DISCUSSION}

In the study period, 117 patients were admitted to the ICU, 95 (81.19\%) of whom met the inclusion criteria (Table 1).

Table 1 - Distribution of patients, by study variable

\begin{tabular}{lccc}
\hline \multicolumn{1}{c}{ Variable } & $\boldsymbol{N}$ & $\%$ & Mean \pm SD \\
\hline Sex & 56 & 58.95 & - \\
Males & 39 & 41.05 & $63.14 \pm 19.51$ \\
Females & - & - & \\
\hline Age (years) & 38 & 40 & \\
Adults & 57 & 60 & - \\
Older adults* & & & \\
\hline Diagnosis & 29 & 30.52 & \\
Pneumonia & 18 & 18.95 & - \\
Sepsis & 14 & 14.74 & \\
AlDS & 34 & 35.79 & \\
Other & - & - & \\
\hline Length of hospital stay (days) & & & \\
\hline Clinical outcome & 2 & 2.10 & \\
Discharge & 3 & 3.16 & - \\
Transfer & 89 & 93.68 & \\
Death & 1 & 1.05 & \\
Extended ICU stay & & & \\
\hline Nutrition therapy & 5 & 5.26 & \\
ENT + PNT & 13 & 13.68 & \\
PNT & 90 & 94.73 & \\
ENT & &
\end{tabular}

* Elderly: $\geq 60$ years; SD: standard deviation; ENT: enteral nutrition therapy; PNT: parenteral nutrition therapy. Source: Authors (2013).

No significant difference in fatal outcomes was observed between the two age groups ( $p$ $=0.850)$. Length of hospital stay was similar for both age groups $(p=0.592)$, but significantly higher $(p=0.005)$ in patients with diarrhea (29.94 \pm 4.80 days) than without diarrhea (13.85 \pm 1.57 days). A significant (albeit not pronounced) positive linear correlation was observed between diarrhea duration and length of hospital stay $(p=0.001 ; r=0.364)$ (Figure 1$)$. 
Figure 1 - Pearson's linear correlation between duration of diarrhea and length of hospital stay

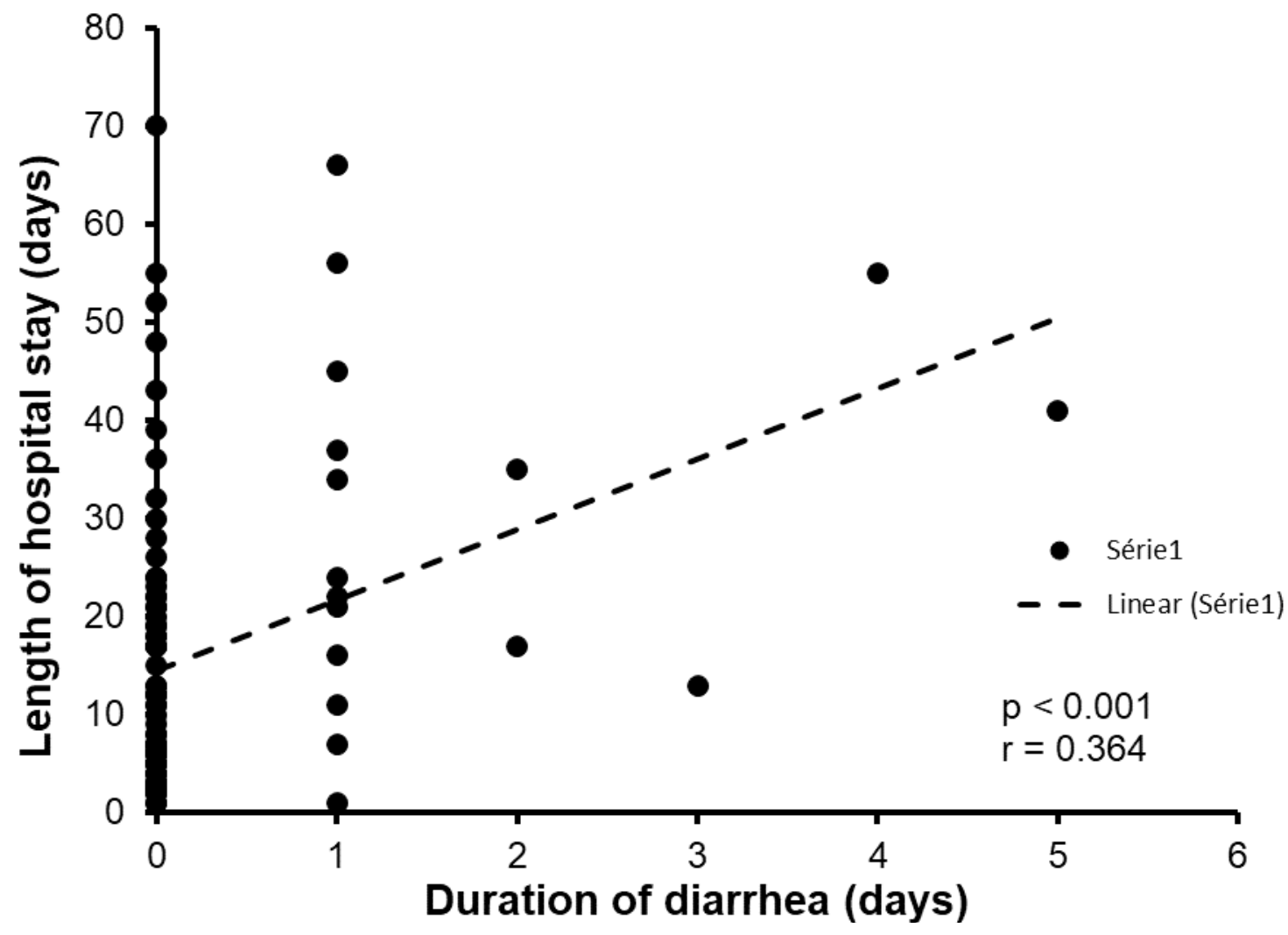

Authors (2013).

No association was observed between nutrition and ensuing hypoglycemia ( $p=0.673$ ) or hyperglycemia ( $p=0.661$ ). Duration of fasting was not associated with prescription $(p=0.529)$, nutritional assessment $(p=0.407)$, or hypoglycemia $(p=0.141)$. However, over $50 \%$ of patients ( $n=53$ ) were fasted for more than 24 h, 39.6\% of whom $(n=21)$ developed hypoglycemia.

Other results shown in Table II are derived from NTQIs.

Table 2-Target rates expected, and results achieved, based on Nutrition Therapy Quality Indicators

\begin{tabular}{|c|c|c|c|}
\hline Indicator $^{1}$ & Equation Formula' & $\begin{array}{c}\text { Result } \\
(\%)\end{array}$ & $\begin{array}{c}\text { Target } \\
\text { rate }\end{array}$ \\
\hline $\begin{array}{l}\text { Frequency of nutritional } \\
\text { screening among } \\
\text { inpatients }\end{array}$ & $\frac{\text { Nutritional screenings per } 24 \mathrm{~h} \times 100}{\text { Total admissions }}$ & 0 & $>80 \%$ \\
\hline \multirow{2}{*}{$\begin{array}{l}\text { Frequency of diarrhea } \\
\text { episodes among patients } \\
\text { on ENT }\end{array}$} & a) $\frac{\text { Patients with diarrhea during ENT } \times 100}{\text { Patients on ENT }}$ & 16.84 & \multirow{2}{*}{$<10 \%$} \\
\hline & 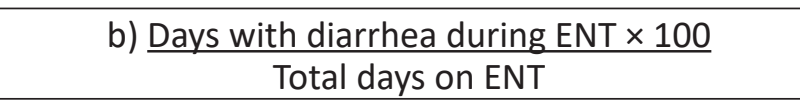 & $2.19 *$ & \\
\hline $\begin{array}{l}\text { Frequency of accidental } \\
\text { dislodgment of nutrition } \\
\text { catheter among patients } \\
\text { on ENT }\end{array}$ & $\frac{\text { Accidental dislodgment of nutrition catheter } \times 100}{\text { Patients on ENT } \times \text { days with enteral catheter }}$ & $0.0026 *$ & $<5 \%$ \\
\hline
\end{tabular}




\begin{tabular}{|c|c|c|c|}
\hline Indicator ${ }^{1}$ & Equation Formula' & $\begin{array}{l}\text { Result } \\
(\%)\end{array}$ & $\begin{array}{l}\text { Target } \\
\text { rate }\end{array}$ \\
\hline \multirow{2}{*}{$\begin{array}{l}\text { Frequency of nutrition } \\
\text { catheter obstruction } \\
\text { among patients on ENT }\end{array}$} & $\begin{array}{l}\text { a) Obstructed enteral catheters } \times 100 \\
\text { Patients on ENT } \times \text { days with enteral catheter }\end{array}$ & $0^{*}$ & \multirow{2}{*}{$<5 \%$} \\
\hline & $\begin{array}{l}\text { b) Obstructed enteral catheters removed } \times 100 \\
\text { Patients on ENT } \times \text { days with enteral catheter }\end{array}$ & 0* & \\
\hline $\begin{array}{l}\text { Frequency of fasting longer } \\
\text { than } 24 \mathrm{~h} \text { among patients } \\
\text { on ENT }\end{array}$ & $\frac{\text { Patients fasting for more than } 24 \mathrm{~h} \times 100}{\text { Patients on NT }}$ & 55.79 & $\leq 12 \%$ \\
\hline \multirow{2}{*}{$\begin{array}{l}\text { Frequency of impaired } \\
\text { glucose levels among } \\
\text { patients on ENT and PNT }\end{array}$} & 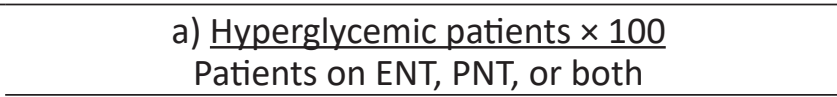 & $68.42 *$ & $70-80 \%^{1}$ \\
\hline & $\begin{array}{l}\text { b) } \text { Hypoglycemic patients } \times 100 \\
\text { Patients on ENT, PNT, or both }\end{array}$ & 32.63 & $\begin{array}{c}5.1- \\
6.9 \% \\
\end{array}$ \\
\hline $\begin{array}{l}\text { Frequency of } \\
\text { measurements of } \\
\text { estimated EE and protein } \\
\text { needs among patients on } \\
\text { NT }\end{array}$ & $\frac{\text { Patients on NT with measured EE } \times 100}{\text { Patients on ENT }}$ & 68.42 & $\geq 80 \%$ \\
\hline $\begin{array}{l}\text { Frequency of CVC infection } \\
\text { among patients on PNT }\end{array}$ & $\frac{\text { Episodes of CVC infection } \times 1000}{\text { Days on catheter }}$ & $6.49 *$ & $<10 \%{ }^{2}$ \\
\hline $\begin{array}{l}\text { Frequency of ENT } \\
\text { nonconformity to } \\
\text { guidelines }\end{array}$ & $\frac{\text { Patients on ENT noncompliant with guidelines } \times 100}{\text { Patients on ENT }}$ & 20.00 & $<13.5 \%$ \\
\hline $\begin{array}{l}\text { Frequency of SGA among } \\
\text { patients on NT }\end{array}$ & $\frac{\text { Patients on NT subjected to SGA } \times 100}{\text { Patients on ENT }}$ & 0 & $>75 \%$ \\
\hline
\end{tabular}

Analysis of NTQIs revealed that no patients underwent nutritional screening, despite a minimum goal of $80 \%$. In a study of Dutch hospitals, Leistra et al. (2014) found that nutritional screening in the first $24 \mathrm{~h}$ of hospitalization ranged from $51.3 \pm 27.9 \%$ in 2007 to $72.116 .8 \%$ in 2010. Higher rates were observed in hospitals that followed screening protocols. Ideally, all hospitalized patients should be screened to identify the degree of complexity required for nutritional care. Nutritional screening has been acknowledged as the initial step in the treatment of malnutrition and should be carried out by the admissions team (RASLAN et al., 2010; RASLAN et al., 2011; POULIA et al., 2012).

In the present study, diarrhea occurred in $16.84 \%$ of patients on ENT-a higher rate than the maximum expected of $10 \%$, even though the percentage of days with diarrhea $(2.19 \%)$ met the established target. Cartolano, Caruso and Soriano (2009) reported a frequency of $6.76 \%$ for diarrhea. Because this is a common complication among critically ill patients (2-95\%), standardizing its definition by means of a protocol to be followed by the multidisciplinary team is a crucial step for diagnosis and treatment of diarrhea (McCLAVE et al., 2016; BTAICHE et al., 2010; POLAGE; SOLNICK; COHEN, 2012).

In the present investigation, accidental removal of enteral nutrition catheters occurred in only three patients - a $0.0026 \%$ rate, desirably lower than the target value $(<5 \%)$, and even lower than that of $0.22 \%$ found by Cartolano, Caruso and Soriano (2009). Obstruction and other mechanical problems with nasogastric tubes can further impair nutritional support (KREYMANN, 2010). 
Of patients on ENT, 55.79\% were fasted for at least 24 h. Ribas, Garcia and Abib (2014) found that $18.49 \%$ of the intercurrences during the ENT were due to a pause for exams or procedures. Among ICU patients, fasting is associated with increased morbidity and mortality (SINGER et al., 2009). Heyland et al. (2010) advocate the use of protocols to decrease the number and duration of fasting periods, thus promoting early implementation of enteral nutrition and reducing barriers to its delivery.

In the present investigation, a satisfactory rate (68.42\%) of hyperglycemia episodes was observed. Hypoglycemia, however, proved more frequent (32.63\%) than desired, an outcome which may have stemmed from a number of factors, including the high prevalence of fasting for more than $24 \mathrm{~h}$ (55.69\%). Nonetheless, no correlation was observed between fasting and hypoglycemia ( $p=0.141$ ) or administration of insulin or hypoglycemic drugs. Although a target range of 140-180 mg/dL for blood glucose has been advocated, protocols should be developed inhouse, based on the profile of patients observed at each ICU (NICE-SUGAR STUDY INVESTIGATORS, 2009; MARTINDALE et al., 2009; McCLAVE et al., 2016).

Of the patients investigated, only $68.42 \%$ had their nutritional needs met, in contrast with the $100 \%$ rate (from a target value of over $80 \%$ ) observed by Cartolano, Caruso and Soriano (2009). Identifying nutritional requirements for specific clinical conditions is crucial to ensure early implementation of an adequate protein energy supply plan (KREYMANN, 2010; SCHÖNHERR, 2012).

A 6.49\% rate of central venous catheter (CVC) infection, meeting the target rate $(<10 \%$ ), was found in the present study. The incidence of infections related to parenteral nutrition CVCS varies from $1.3 \%$ to $26.2 \%$-one of the most serious complications of parenteral nutrition. However, previous research attempting to identify PNT as an independent cause of CVC infection has proved inconclusive (SHIROMA et al., 2015).

The indicator employed to evaluate ENT conformity with guidelines revealed a higher nonconformity rate $(20.00 \%)$ than the proposed target $(<13.5 \%)$. Analysis of this indicator was based on international recommendations on type of support and protein-energy supply (SINGER et al., 2009; McCLAVE et al., 2016; MARTINDALE et al., 2009; SCHÖNHERR et al., 2012).

Finally, Subjective Global Assessment (SGA) frequency was zero, in stark contrast with the proposed target of over 75\%. SGA has been considered a gold standard for nutritional assessment in the hospital setting, for its validity, reliability, and ease of use (RASLAN et al., 2011; AGARWAL et al., 2012; POULIA et al., 2012; VEROTTI et al., 2012).

NTQIs can reveal the effectiveness of processes, identifying critical points, conformities, and potentialities in nutrition support (WAITZBERG, 2008; VEROTTI et al., 2012). The ICU investigated belonged to a teaching hospital where turnover of residents from different backgrounds is high and protocols for routines and nutrition therapy procedures are lacking-features that can explain the results obtained, given the variability of policies adopted by different professionals, not always corresponding to the guidelines governing this investigation. The absence of specific protocols for assessing the factors preventing appropriate nutritional support in more detail represents a limiting factor. Moreover, failures in nutrition therapy cannot be attributed to a lack of protocols. Schönherr et al. (2012) raised the possibility of team members holding insufficient knowledge of nutrition. Protocol implementation should be combined with in-service training and continuing education for all team members involved at some point in the nutrition support process (HEYLAND et al., 2010). 
In the present study, non-conformities and weaknesses in nutrition support were identified with respect to the goal of NTQIs - namely, facilitating the achievement of high-quality as part of a quality assurance effort in nutrition therapy, intended to provide efficient routines, reduced costs, and practices founded on the scientific literature, with the ultimate goal of improving clinical outcomes and quality of life among critically ill patients performance (VEROTTI et al., 2012; CENICCOLA; ARAÚJO; AKUTSU, 2014).

\section{CONCLUSION}

This study, the first applying NTQIs to reveal the quality of nutrition therapy at the ICU investigated, allowed non-compliances to be identified and corrective measures to be suggested, thereby ensuring an adequate supply of nutrients, based on nutritional assessment measures and continuous monitoring, and maintaining or restoring the nutritional status of critically ill patients, with a positive impact on their evolution during hospitalization.

\section{REFERENCES}

AGARWAL, Ekta; FERGUSON, Maree; BANKS, Merrilyn; BAUER, Judith; CAPRA, Sandra; ISENRING, Elisabeth. Nutritional status and dietary intake of acute care patients: results from the Nutrition Care Day Survey 2010. Clinical Nutrition, Edimburgo, v. 31, n. 1, p. 41-7, Sept. 2012. DOI: https://doi.org/10.1016/j. clnu.2011.08.002

BRAUN, Jan-Peter; KUMPF, Oliver; DEJA, Maria; BRINKMANN, Alexander; MARX, Gernot; BLOOS, Frank; KALTWASSER, Arnold; DUBB, Rolf; MUHL, Elke; GREIM, Clemens; BAUSE, Hanswerner; WEILER, Norbert; CHOP, Ines; WAYDHAS, Christian; SPIES, Claudia. The German quality indicators in intensive care medicine 2013 - second edition. GMS German Medical Science, Berlim, v. 11, p. 1-17, July 2013. DOI: https://doi. org/10.1177/0884533611432317

BTAICHE, Imad F.; CHAN, Lingtak-Neander; PLEVA, Melissa; KRAFT, Michael D. Critical illness, gastrointestinal complications, and medication therapy during enteral feeding in critically ill adult patients. Nutrition in Clinical Practice, Bethesda, v. 25, n. 1, p. 32-49, Feb. 2010. DOI: https://doi.org/10.1177\%2F0884533609357565

CARTOLANO, Flávia De Conti; CARUSO, Lúcia; SORIANO, Francisco Garcia. Enteral nutritional therapy: application of quality indicators. Revista Brasileira de Terapia Intensiva, São Paulo, v. 21, n. 4, p. 376-83, Oct. 2009. DOI: http://dx.doi.org/10.1590/S0103-507X2009000400007

CENICCOLA, Guilherme Duprat; ARAÚJO, Wilma Maria Coelho; AKUTSU, Rita. Development of a tool for quality control audits in hospital enteral nutrition. Nutrición Hospitalaria, Madrid, v. 29, n. 1, p. 102-20, Oct. 2014. DOI: 10.3305/nh.2014.29.1.7071

CUNHA, Haroldo Falcão Ramos da; SALLUH, Jorge Ibrain Figueira; FRANÇA, Maria de Fátima. Atitudes e percepções em terapia nutricional entre médicos intensivistas: um inquérito via internet. Revista Brasileira de Terapia Intensiva, São Paulo, v. 22, n. 1, p. 53-63, Mar. 2010. DOI: http://dx.doi.org/10.1590/S0103$507 \times 2010000100010$

HEYLAND, Daren K.; CAHILL, Naomi E.; DHALIWAL, Rupinder; SUN, Xiaoqun; DAY, Andrew G.; MCCLAVE, Stephen A. Impact of enteral feeding protocols on enteral nutrition delivery: results of a multicenter observational study. Journal of Parenteral and Enteral Nutrition, Silver Spring, v. 34, n. 6, p. 675-84, Nov./ Dec. 2010.

KREYMANN, Georg. New developments in clinical practice guidelines. South African Journal of Clinical Nutrition, Lyttelton, v. 23, n. sup. 1, p. 29-32, 2010. DOI: http://dx.doi.org/10.1080/16070658.2010.11734266 
LEE, Ariana; OLIVEIRA FILHO, Ronaldo Sousa; CARDENAS, Thais de Campo; OZÓRIO, Gislaine Aparecida; GROPP, Juliana Pereira Lima; WAITZBERG, Dan Linetzky. Quality control of enteral nutrition therapy in cancer patients at nutritional risk. Nutrición Hospitalaria, Madrid, v. 34, n. 2, p. 264-70, Mar. 2017.

LEISTRA, Eva; VANBOKHORST-DEVANDERSCHUEREN, Marian; VISSER, Marjolein; VANDERHOUT, Anja; LANGIUS, Jacqueline; KRUIZENGA, Hinke M. Systematic screening for under nutrition in hospitals: predictive factors for success. Clinical Nutrition, Edimburgo, v. 33, n. 3, p. 495-501, June 2014. DOI: https://doi. org/10.1016/j.clnu.2013.07.005

MARTINDALE, Robert G.; MCCLAVE, Stephen A.; VANEK, Vincent W.; MCCARTHY, Mary; ROBERTS, Pamela; TAYLOR, Beth; OCHOA, Juan B.; NAPOLITANO, Lena; CRESCI, Gail. Guidelines for the provision and assessment of nutrition support therapy in the adult critically ill patient: Society of Critical Care Medicine and American Society for Parenteral and Enteral Nutrition: Executive Summary. Critical Care Medicine, Mount Prospect, v. 37, n. 5, p. 1757-61, May 2009. DOI: 10.1097/CCM.0b013e3181a40116

MCCLAVE, Stephen A.; TAYLOR, Beth E.; MARTINDALE, Robert G.; WARREN, Malissa M.; JOHNSON, Debbie R.; BRAUNSCHWEIG, Carol; MCCARTHY, Mary S.; DAVANOS, Evangelia; RICE, Todd W.; CRESCI, Gail A.; GERVASIO, Jane M.; SACKS, Gordon S.; ROBERTS, Pamela R.; COMPHER, Charlene. Guidelines forth e provision and assessment of nutrition support therapy in the adult critically ill patient: Society of Critical Care Medicine (SCCM) and American Society for Parenteral and Enteral Nutrition (ASPEN). Journal of Parenteral and Enteral Nutrition, Silver Spring, v. 40, n. 2, p. 159-211, 2016. DOI: https://doi. org/10.1177/0148607115621863

NICE-SUGAR STUDY INVESTIGATORS. Intensive versus conventional glucose control in critically ill patients. The New England Journal of Medicine, Waltham, v. 360, n. 13, p. 1283-97, Mar. 2009. DOI: https://doi. org/10.1056/NEJMoa0810625

POLAGE, Christopher R.; SOLNICK, Jay V.; COHEN, Stuart H.Nosocomial diarrhea: evaluation and treatment of causes other than Clostridium difficile. Clinical Infectious Diseases, Oxford, v. 55, n. 7, p. 982-9, Oct. 2012. DOI: https://doi.org/10.1093/cid/cis551

POULIA, Kalliopi-Anna; YANNAKOULIA, Mary; KARAGEORGOU, Dimitra; GAMALETSOU, Maria; PANAGIOTAKOS, Demosthenes B.; SIPSAS, Nikolaos V.; ZAMPELAS, Antonis. Evaluation of the efficacy of six nutritional screening tools to predict malnutrition in the elderly. Clinical Nutrition, Edimburgo, v. 31, n. 3, p. 378-85, Jun. 2012. DOI: https://doi.org/10.1016/j.clnu.2011.11.017

RASLAN, Mariana; GONZALEZ, Maria Cristina; DIAS, Maria Carolina Gonçalves; NASCIMENTO, Mariana; CASTRO, Melina; MARQUES, Patrícia; SEGATTO, Sabrina; TORRINHAS, Raquel Susana; CECCONELLO, Ivan; WAITZBERG, Dan Linetzkyet. Comparison of nutritional risk screening tools for predicting clinical outcomes in hospitalized patients. Nutrition, Burbank, v. 26, n. 7, p. 721-6, Jul. 2010. DOI: https://doi. org/10.1016/j.nut.2009.07.010

RASLAN, Mariana; GONZALEZ, Maria Cristina; TORRINHAS, Raquel Suzana M. M.; RAVACCI, Graziela Rosa; PEREIRA, Julio C. R.; WAITZBERG, Dan L. Complementarity of Subjective Global Assessment (SGA) and Nutritional Risk Screening 2002 (NRS2002) for predicting poor clinical outcomes in hospitalized patients. Clinical Nutrition, Edimburgo, v. 30, n. 1, p. 49-53, Feb. 2011. DOI: https://doi.org/10.1016/j.clnu.2010.07.002

RIBAS, Bruna Luiza P.; GARCIA, Rosane Scussel; ABIB, Renata Torres. Motivos para interrupção da terapia nutricional enteral em pacientes hospitalizados. Revista Brasileira de Nutrição Clínica, São Paulo, v. 29, n. 4, p. 331-4, Sept. 2014.

SCHÖNHERR, Silvia; HALFENS, Ruud J. G.; MEIJERS, Judith M. M.; SCHOLS, Jos M. G. A.; LOHRMANN, Christa. Structural and process indicators of nutritional care: a comparison between Austrian hospitals and nursing homes. Nutrition, Burbank, v. 28, n. 9, p. 868-73, Sept. 2012. DOI: https://doi.org/10.1016/j.nut.2011.11.007 
SHIROMA, Glaucia Midori; HORIE, Lilian Mika; CASTRO, Melina Gouveia; MARTINS, Juliana R.; BITTENCOURT, Amanda F.; LOGULLO, Luciana; SILVA, Maria de Lourdes Teixeira da; WAITZBERG, Dan L. Nutrition quality control in the prescription and administration of parenteral nutrition therapy for hospitalized patients. Nutrition in Clinical Practice, Bethesda, v. 30, n. 3, p. 406-13, Jun. 2015. DOI: https:// doi.org/10.1177\%2F0884533614567540

SINGER, Pierre; Berger, Mette M.; VANDENBERGHe, Greet; BIOLO, Gianni; CALDER, Philip; FORBES, Alastair; GRIFFITHS, Richard; KREYMAN, Georg; LEVERVE, Xavier; PICHARD, Claude. ESPEN guidelines on parenteral nutrition: intensive care. Clinical Nutrition, Edimburgo, v. 28, n. 4, p. 387-400, Feb.2009. DOI: https://doi.org/10.1016/j.clnu.2009.04.024

VALENTIN, Andreas; FERDINANDE, Patrick; ESICM Working Group on Quality Improvement. Recommendations on basic requirements for intensive care units: structural and organizational aspects. Intensive Care Medicine, Ottawa, v. 37, n. 10, p. 1575-87, Sept. 2011. DOI: https://doi.org/10.1007/ s00134-011-2300-7

VEROTTI, Cristiane Comeron Gimenez; TORRINHAS, Raquel Susana Matos de Miranda; CECCONELLO, Ivan; WAITZBERG, Dan Linetzky. Selection of top 10 quality indicators for nutrition therapy. Nutrition in Clinical Practice, Bethesda, v. 27, n. 2, p. 261-7, Jan. 2012. DOI: https://doi.org/10.1177\%2F0884533611432317

WAITZBERG, Dan L. Indicadores de qualidade em terapia nutricional. 1. ed. São Paulo: ILSI Brasil, 2008.

\section{About the authors:}

Teresa Cristina Abranches Rosa - Master's Degree in Metabolism and Nutrition by the PostGraduate Program in Health and Development in the Center-West Region (UFMS). Specialization by the Multiprofessional Health Residency Program - Attention to the Critical Patient, from UFMS, Maria Aparecida Pedrossian University Hospital (HUMAP). Graduation in Nutrition by the Federal University of Viçosa (UFV). Nutritionist at UFMS, tutor in the Multiprofessional Health Residency Program - UFMS /HUMAP/EBSERH Critical Patient Care, tutor in the Multiprofessional Residency Program in Integrated Continuing Care, Area of Concentration: Health Care of the Elderly (PREMUS CCI) UFMS / HOSPITAL SÃO JULIÃO / ESP / SES. Professor at Nutrition Course at Campo Grande College (FCG). E-mail: teresacristinaar@yahoo.com.br, Orcid: http://orcid.org/0000-0002-9990-6560

Mariana Raslan - PhD from the Faculty of Medicine of the University of São Paulo. Specialist in Clinical Nutrition by GANEP (Human Nutrition). Adjunct Professor, Faculty of Medicine, Federal University of Mato Grosso do Sul (UFMS). Performance in the area of clinical nutrition, malnutrition and nutritional screening of hospitalized patients. E-mail: marianaraslan@hotmail.com, Orcid: http://orcid.org/0000-0001-5876-9443

Albert Schiaveto de Souza - Postdoctoral studies at the University of Oxford,UK. Amaster's degree and a doctorate in Sciences (Physiology) from the University of São Paulo, Ribeirão Preto campus. Graduation in Physiotherapy from the State University of Londrina (UEL). He has associate professor at the undergraduate level at the Federal University of Mato Grosso do Sul (UFMS). He has accredited counselor in the Post-Graduate Program in Health and Development in the Central-West Region; Post-Graduate Program in Dentistry at UFMS; Graduate Program in Family Health and collaborator in the Master's Program in Pharmacy at UFMS, and is the current director 
of the Biosciences Institute at UFMS. Evaluator of INEP/MEC for the Physiotherapy course. He has experience in the areas of Physical Therapy and Neurophysiology, acting mainly in the following subjects: neuronal plasticity, spatial memory, physiology of the genes of the base of the brain and biostatistics. E-mail: albertss@hotmail.com, Orcid: http://orcid.org/0000-0003-0017-672X

Karine de Cássia Freitas - Master's degree and doctorate in Sciences from the Federal University of São Paulo (UNIFESP). Graduation in nutrition by Federal University of Ouro Preto, She has experience in the area of Clinical and Experimental Nutrition. Currently is an Professor in the Nutrition Course of the Federal University of Mato Grosso do Sul (UFMS) and permanent professor of the Post-Graduation Program in Health and Development in the Center-West Region (UFMS).

E-mail: kcfreitas@gmail.com, Orcid: http://orcid.org/0000-0002-5813-6088 